\title{
Analisis Pengaruh Pengembangan Karir Dan Iklim Organisasi Terhadap Kepuasan Kerja Karyawan Pada PT.PLN (Persero) UIW, S3JB UP 3 Lahat
}

\author{
Melia Andayani \\ Manajemen STE Serelo Lahat, lia82yani@gmail.com
}

\begin{abstract}
ABSTRAK
Penelitian ini bertujuan untuk mengetahui Pengaruh pengembangan karir dan iklim organisasi terhadap kepuasan kerja karyawan pada PT. PLN (PERSERO) UIW, S3JB UP 3 Lahat, jumlah responden didalam penelitian ini sebanyak 40 orang, Metode analisis yang digunakan adalah analisis diskriptif kuantitatif dan kualitatif, Analisis diskriptif Kualitatif yaitu dengan membanding antara teori dan kenyataan yang ada sedangkan analisis kuantitatif adalah analisis dengan menggunakan perhitungan statistik. Teknik pengumpulan data melalui observasi, wawancara dan kuisioner. Analisi regresi berganda dilakukan untuk menguji hipotesis. Dari hasil Analisis Kuantitatif didapat persamaan $Y=Y=8.602+0,254 X_{1}+0,239 X_{2}$ artinya dengan adanya pengembangan karir dan iklim organisasi akan mempengaruhi kepuasan kerja sebesar 8.602.
\end{abstract}

Kata Kunci : Pengembangan Karir, Iklim Organisasi, Kepuasan Kerja

\section{A. PENDAHULUAN}

Sumber daya manusia merupakan unsur yang sangat penting dalam suatu perusahaan. Oleh karena itu setiap perusahaan selalu berupaya untuk memiliki sumber daya yang berkualitas, karena tanpa sumber daya manusia yang berkualitas suatu perusahaan tidak akan berjalan dengan baik.

Sebagai dua pihak yang saling membutuhkan maka diperlukan terciptanya hubungan yang harmonis diantara keduanya. Ketika hubungan harmonis antara karyawan dengan perusahaan telah tercipta dengan baik, maka suasana kerja pun semakin baik dan berdampak pada kepuasan kerja karyawan yang meningkat. Kepuasan kerja merupakan hal yang penting dimiliki oleh setiap orang dalam bekerja. Tingkat kepuasan kerja yang tinggi akan mempengaruhi seseorang dalam menyelesaikan pekerjaannya. Sehingga tujuan perusahaan dapat dicapai dengan baik. Begitu pun sebaliknya, rendahnya kepuasan kerja karyawan dalam suatu perusahaan akan menurunkan efektifitas dan efisiensi kerja mereka sehingga tujuan perusahaan tidak tercapai dengan baik.

Kepuasan kerja pada dasarnya merupakan sesuatu yang sifatnya individual dan setiap individu memiliki tingkat kepuasan yang berbeda-beda. Hal tersebut dapat dilihat dari sikap dan bagaimana cara mereka menyelesaikan suatu pekerjaan yang diberikan. Jika karyawan tersebut menyukai pekerjaannya dan dapat menyelesaikan tugas dari perusahaan dengan baik, maka sudah dapat dipastikan karyawan tersebut memiliki rasa puas atas pekerjaanya.

Upaya yang dapat dilakukan untuk meningkatkan kepuasan kerja karyawan adalah perusahaan harus memperhatikan pengembangan karir karyawan. pengembangan karir sangat erat hubungannya untuk menciptakan efisiensi kerja organisasi. pentingnya 
melakukan pengembangan karir bagi karyawan akan merasa terbantu dalam bekerja dan dalam mencapai karir yang diinginkan, karyawan merasa dihargai dan diperhatikan sehingga akan meningkatkan kepuasan kerja karyawan.

Selain itu, Untuk menciptakan kepuasan kerja, iklim organisasi juga merupakan salah satu faktor yang dapat mempengaruhi kepuasan kerja karyawan.. Iklim organisasi yang positif akan memberikan hasil kerja yang positif,sebaliknya iklim organisasi yang negatif akan memberikan hasil kerja yang negatif juga.

Oleh sebab itu, perhatian terhadap iklim organisasi sangat diperlukan karena Iklim organisasi merupakan suatu wadah bagi para karyawan berinteraksi dan bekerja sama satu sama lain dalam mencapai tujuan organisasi.

Berdasarkan observasi yang terjadi di PT. PLN (PERSERO) UIW, S2JB UP 3 Lahat menurunnya kepuasan kerja karyawan dapat dilihat dari karyawan tidak mempunyai kesempatan menggunakan metode sendiri dalam menyelesaikan tugas yang diberikan serta pekerjaan yang diberikan tidak sesuai dengan keterampilan yang dimiliki,dalam melaksanakan pekerjaan masih ada karyawan yang tidak saling mendukung dalam bekerja serta dalam melaksanakan pekerjaan antara persepsi dengan pekerjan tidak sesuai. Selain itu, masih ada beberapa karyawan yang belum mengikuti pelatihan dalam mengembangkan karir karyawan.

\section{B. KAJIAN TEORI}

1) Pengertian Kepuasan kerja

Kepuasan kerja pada dasarnya merupakan sesuatu yang bersifat individual. Setiap individu memiliki tingkat kepuasan yang berbeda sesuai dengan sistem nilai yang berlaku pada dirinya. Makin tinggi penilaian terhadap kegiatan dirasakan sesuai dengan keinginan individu, maka makin tinggi kepuasannya terhadap kegiatan tersebut. Dengan demikian, kepuasan merupakan evaluasi yang menggambarkan seseorang atas perasaan sikapnya senang atau tidak senang, puas atau tidak puas dalam bekerja (Rivai, 2013:856).

Menurut Sunyoto (2012:210) kepuasan kerja (Job satisfaction) adalah keadaan emosional yang menyenangkan atau tidak menyenangkan dimana para karyawan memandang pekerjaannya. Kepuasan kerja mencerminkan perasaan seseorang terhadap pekerjaan.

Kepuasan kerja secara umum merupakan sikap terhadap pekerjaan yang didasarkan pada evaluasi terhadap aspek-aspek yang berbeda bagi pekerja. Sikap seseorang terhadap pekerjaannya tersebut menggambarkan pengalamanpengalaman menyenangkan atau tidak menyenangkan dalam pekerjaan dan harapan-harapan mengenai pengalaman mendatang. Sementara itu, Osborn dalam Sunarso (2010:5) mendefinisikan kepuasan kerja adalah derajat positif atau negatif perasaan seseorang mngenai segi tugas-tugas pekerjaannya, tantangan kerja serta hubungan antar sesama pekerja.

Kepuasan

dapat menggambarkan perasaan positif dan negatif pegawai dari persepsi terhadap pekerjaan yang dihadapinya, seperti perasaan untuk berprestasi dan meraih kesuksesan didalam pekerjaan, menginplementasikan kepuasan yang tinggi terhadap karyawan/pegawai yang merasa senang dan nyaman dengan kondisi lingkungan organisasi dan mendapatkan penghagaan dari hasil kerjanya (Aziri,2011). 
Berdasarkan beberapa pendapat diatas, dapat disimpukan bahwa kepuasan merupakan sesuatu yang bersifat individual. Dengan kata lain, kepuasan merupakan evalasi yang menggambarkan perasaan seseorang atas sikapnya. Senang atau tidak senang, puas atau tidak puas dalam bekerja.

Menurut Veithzal (2013:859) faktor-faktor yang mempengaruhi kepuasan kerja karyawan pada dasarnya secara praktis dapat dibedakan menjadi dua kelOmpok yaitu:

\section{Faktor Intrinsik}

Faktor intrinsik adalah faktor yang berasal dari dalam diri karyawan dan dibawa oleh setiap karyawan sejak mulai bekerja di tempat pekerjaanya.

2. Faktor ekstrinsik

Faktor ekstrinsik menyangkut halhal yang berasal dari luar diri karyawan, antara lain kondisi fisik lingkungan kerja, interaksi dengna karyawan lain, sistem penggajian.

Menurut Handoko (2005) dalam Fitri (2016:9) iklim organisasi juga merupakan faktor yang mempengaruhi kepuasan kerja karyawan, dimana iklim organisasi menggambarkan suasana lingkungann kerja menyenangkan atau tidak menyenangkan, menggambarkan penyelia yang baik atau tidak baik sehingga mempengaruhi bagaimana kepuasan kerja karyawan.

\section{Indikator-Indikator Kepuasan Kerja}

\section{Menurut Veithzal Rivai} (2013:860) mengemukakan indikatorindikator kepuasan kerja adalah sebagai berikut:

\section{Isi pekerjaan}

Setiap pekerjaan memerlukan suatu keterampilan tertentu.
Biasanya karyawan lebih menyukai pekerjaan yang memberian peluang kepada karyawan untuk menggunakan keterampilan dan kemauan.

2. Supervisi.

Penyelia yang baik berarti mau menghargai pekerjaan bawahannya. Bagi bawahan, penyelia sering dianggap sebagai figur atasan.

3. Organisasi dan manajemen.

Organisasi dan manajemen yang baik akan memperhatikan kesejateraan karyawan dengan mengupayakan berbagai cara untuk mempertahankan, memotivasi dan menciptakan kepuasan kerja karyawan.

4. Kesempatan untuk maju.

Kesempatan untuk maju merupakan faktor yang berhubungan dengan ada tidaknya kesempatan untuk memperoleh peningkatan karir selama bekerja.

5. Pembayaran (upah/gaji).

Karyawan menginginkan suatu sisten pembayaran yang mereka anggap adil, tidak bermakna ganda dan sesuai dengan harapan mereka.

6. Rekan kerja.

Mitra kerja ramah dan mendukung mendorong kepuasan kerja karyawan

7. Kondisi kerja.

Karyawan peduli dengan lingkungan kerja yang nyaman dan mendukung pekerjaan mereka.

\section{2) Pengertian Pengembangan Karir}

Suatu karir mencerminkan perkembangan para anggota organisasi (karyawan) secara individu dalam jenjang jabatan atau kepangkatan yang dapat dicapai 
selama masa kerja dalam organisasi yang bersangkutan. Dengan demikian, suatu karir menunjukan orang-orang pada masing-masing peranan atau status mereka. Karir pada dasarnya merupakan istilah teknis dalam administrasi personalia. Menurut Mondy (2012:28) pengembangan karir adalah pendekatan formal yang digunakan perusahaan untuk memastikan bahwa orang-orang dengan kualifikasi dan pengalaman yang tepat, tersedia saat dibutuhkan. Hal serupa juga diungkapkan ole Nawawi (2008) dalam Widya Pramita (2015:334) yang mengatakan bahwa pengembangan karir adalah usaha yang dilakukan secara formal dan berkelanjutan dengan difokuskan pada peningkatan dan penambahan kemampuan seorang pekerja.

Pengembangan karir menurut Komang (Sunyoto, 2012:183) adalah peningkatan pribadi yang dilakukan seseorang untuk mencapai suatu rencana karir dan peningkatan oleh departemen personalia untuk mencapai suatu rencana kerja sesuai dengan jalur atau jenjang organisasi. Menurut Warjono pengembangan karir merupakan upaya pribadi seseorang karyawan dalam mewujudkan karirnya yang bisa didukung oleh departement SDM.

Dari penjelasan diatas dapat disimpulkan bahwa pengembangan karir merupakan usaha pribadi karyawan yang ditunjukan untuk menuju rencana karirnya melalui pendidikan, pelatihan, dan perolehan kerja serta pengalaman. Selain itu, pengembangan karir juga merupakan usaha formal untuk meningkatkan dan menambah kemampuan seorang pekerja yang dapat membuka kesempatan untuk mencapai suatu rencana karir selama masa bekerja.
Menurut Sunyoto (2012:173) ada lima faktor yang terkait dengan pengembangan karir karyawan:

1. Keadilan dalam berkarir karyawan, menghendaki keadilan dalam sistem promosi dengan kesempatan sama untu meningkatkan karir

2. Perhatian penyelia, para karyawan menginginkan penyelia mereka memainkan peran aktif dalam pengembangan karir dan menyediakan upan balik dengan teratur tentang prestasi

3. Kesadaran tentang kesempatan, karyawan menghendaki pengetahuan tentang kesempatan untuk peningkatan karir.

4. Minat pekerja, para karyawan membutuhkan sejumlah informasi berbeda.

5. Kepuasan karir, para karyawan tergantung pada usia dan kedudukan mereka dan memiliki tingkat kepuasan yang berbeda.

\section{Indikator Pengembangan Karir}

Pengembangan karir merupakan upaya-upaya pribadi seorang karyawan untuk mencapai karir. Kegiatan-kegiatan ini perlu didukung perusahaan. Adapun indikatorindikator pengembangan karir menurut Veithzal Rivai (2013) adalah sebagai berikut:

1. Kebutuhan karir

Membantu para karyawan dalam menyesuaikan kebutuhan karir internal mereka sendiri.

2. Dukungan perusahaan dalam bentuk Moril

Perusahaan memberikan umpan balik terhadap kinerja yaitu dengan meningkatkan kemampuan kinerja karyawan untuk mengisi posisi jabatan / karir yang disediakan oleh perusahaan. 
3. Dukungan perusahaan dalam bentuk materil

Perusahaan memberikan umpan balik berupa fasilitas-fasilitas kerja yang mendukung dalam jabatannya.

4. Pelatihan

Meningkatkan
karyawan dalam
operasional.

5. Perlakuan yang adil dalam berkarir

Memberikan kesempatan berkarir kepada karyawannya untuk mengembangkan diri.

6. Informasi karir

Memberikan informasi kebutuhan karir yang dibutuhkan untuk mengetahui kemungkinan jabatan yang dapat dicapai karyawan untuk mengembangkan diri

7. Promosi

Memberikan pengakuan, jabatan, dan imbalan jasa yang semakin besar kepada karyawan yang berprestasi tinggi

8. Pengembangan tenaga kerja Memberikan program pendidikan dan pelatihan untuk karyawan untuk meningkatkan potensi dalam dirinya

Pengembangan karir tidak hanya tergantung pada usaha individu saja, karena hal itu tidak selalu sesuai dengan kepentingan organisasi. untuk mengarahkan pengembangan karir agar menguntungkan organisasi dan karyawan, perusahaan perlu mengusahakan dukungan manajemen, memberikan umpan balik kepada karyawan dan membangun suatu lingkungan kerja yang nyaman untuk meningkatkan kemampuan dan keinginan karyawan dalam melaksanakan pengembangan karir.

\section{3) Pengertian Iklim Organisasi}

Iklim atau Climate berasal dari bahasa Yunani yaitu incline, kata ini tidak hanya memberikan arti yang terbatas pada hal-hal fisik saja seperti temperatur atau teknan, tetapi juga memilik arti psikologis bahwa orangorang yang berada di dalam organisasi menggambarkan tentang lingkungan internal organisasi tersebut.

$$
\text { Istilah iklim organisasi }
$$

(organizational climate) dipakai oleh R. Tagiuri dan G.Litwin. Tiaguri mengemukakan sejunlah istilah untuk melukiskan perilaku dalam hubungan dengan latar atau tempat (setting) dimana perilaku muncul: lingkungan (environment), lingkungan pergaulan (miliue), budaya (culture), suasana (atmosphere), situasi (situation), pola lapangan (field setting), dan kondisi (condition). Iklim organisasi merupakan suatu keadaan yang ada di lingkungan organisasi yang tercipta dalam suatu organisasi yang menggambarkan keadaan atau kondisi kerja dalam organisasi. Iklim organisasi merupakan hal yang perlu mendapat perhatian seorang manejer karena faktor tersebut ikut mempengaruhi tingkah laku karyawan dalam organisasi. Membahas tentang iklim organisasi, berarti membahas tentang sifat-sifat atau ciri yang dirasakan dalam lingkungan kerja dan timbul terutama karena kegiatan organisasi yang dilakukan secara sadar atau tidak, dan dianggap mempengaruhi tingkah laku. Dengan demikan, iklim dapat dipandang sebagai kepribadiaan organisasi Kadarisma (2013)

Menurut Payne dalam Fitri (2016:2) mendefinisikan iklim organisasi sebagai suatu konsep yang mereflesikan sisi dan kekuatan dari nilai-nilai umum, norma,sikap dan timgkah laku dan perasaan anggota terhadap suatu sistem. 
Kemudian dikemukakan oleh simamora yang dikutip oleh Lila (2011:4) disebutkan bahwa iklim organisasi adalah lingkungan internal atau psikologi organisasi yang menggambarkan adanya bentuk iklim organisasi yang terbuka atau tertutup. Sedangkan Howard juga mengatakan dalam Halim (2010:5) iklim organisasi sebagai keadaan sosial dan budaya yang mempengaruhi tingkah laku orang didalam nya.

Dari beberapa teori diatas dapat disimpulkan bahwa iklim organisasi merupakan bentuk keadaan dalam lingkungan internal organisasi dan iklim organisasi yang dimaksud adalah lingkungan internal yang berisikan gagasan-gagasan yang menggambarkan fungsi atau tujuan perusahan berupa kebijakan, prosedur, peraturan, baik formal maupun informal yang dibuat untuk pencapaian tujuan tersebut yang berpengaruh terhadap perilaku anggota dan organisasi itu sendiri

\section{Indikator-indikator iklim organisasi}

Menurut Campbell dalam Lila (2011:5) ada sepuluh indikator iklim tingkat organisasi secara keseluruhan. Demensi-demensi itu adalah:

1. Struktur Tugas. Tingkat perincian metode yang dipakai untuk melakukan tugas oleh organisasi.

2. Hubungan imbalan-hukuman. Tingkat batas pemberian imbalan tambahan seperti promosi dan kenaikan gaj didasakan pada prestasi dan jasa dan bukan pertimbangan-pertimbangan lain seperti senioritas, dan favoritas.

3. Sentralisasi keputusan. Batas keputusan -keputusan penting dipusatkan pada manajemen atas

4. Tekanan pada prestasi. Keinginan pihak pekerja organisasi untuk melaksanakan pekerjaan dengan baik dan memberikan sumbangannya bagi sasaran karya organisasi.

5. Tekanan pada latihan dan pengembangan. Tingkat batas organisasi berusaha meningkatkan prestasi individu melalui kegiatan latihan dan pengembangan yang tepat.

6. Keamanan. Tingkat batas tekanan dalam organisasi menimbulkan perasaan kurang aman dan kecemasan pada para anggotanya.

7. Keterbukaan. Tingkat batas orangorang kebih suka berusaha menutupi kesalahan mereka dan menampilkan secara baik dari pada berkomunikasi secara bebas dan bekerjasama.

8. Status dan semangat. Perasaan umum diantara para individu bahwa organisasi merupakan tempat bekerja yangbaik.

9. Pengakuan dan umpan balik. Tingkat batas seorang individu mengetahui apa pendapat atasannya dan manajemen mengenal pekerjaannya serta tingkat batas dukungan mereka batas dirinya.

10. Kompetensi dan keluwesan organisasi secara umum. Tingkat batas organisasi mengetahui apa tujuannya dan mengerjakan secara luwes dan kreatif. termasuk juga batas organisasi mengantisipasi masalah, mengembangkan metode baru, dan mengembagkan keterampilan baru.

\section{METODE PENELITIAN}

Penelitian ini merupakan penelitian assosiatif kausal dengan menggunakan pendekatan kuantitatif. Penelitian assosiatif kausal adalah penelitian yang bertujuan untuk 
mengetahui pengaruh antara dua variabel atau lebih (Sugiyono, 2013:37).

Dalam penelitian ini peneliti menggunakan jenis penelitian deskriptif dengan menggunakan pendekatan kuantitatif. Menurut Sugiyono (2013: 8) penelitian kuantitatif merupakan penelitian dengan memperoleh data yang berbentuk angka atau data kuantitatif yang diangkakan. Penelitian dianalisis sesuai dengan metode statistik yang digunakan kemudian di interprestasikan. Dalam penelitian ini menganalisis pengembangan karir (X1) dan iklim organisasi (X2) terhadap kepuasan kerja karyawan pada PT. PLN (PERSERO) UIW, S2JB UP 3 Lahat.

\section{POPULASI DAN SAMPEL}

\section{1) Populasi}

Populasi adalah wilayah generalisasi yang terdiri atas obyek/subyek yang mempunyai kualitas dan karateristik tertentu yang ditetapkan oleh peneliti untuk dipelajari dan kemudian ditarik kesimpulan (Sugiyono 2013: 80).

Populasi dalam penelitian ini adalah seluruh karyawan di PT. PLN (PERSERO) UIW, S2JB UP 3 Lahat yang berjumlah 40 orang karyawan

\section{2) Sampel}

Sampel adalah bagian dari jumlah dan karakteristik yang dimiliki oleh populasi. Jumlah populasi dalam penelitian ini 40 orang karyawan maka semua dijadikan sampel peneltian. Dalam penelitian ini menggunakan metode sensus (sampling Jenuh). Metode Sensus yaitu teknik penentuan sampel bila semua anggota populasi digunakan sebagai sampel. Hal ini sering dilakukan bila jumlah populasi relatif lebih kecil. (Sugiyono 2013:83).
E. TEKNIK PENGUMPULAN DATA Adapun teknik pengumpulan data dalam penelitian ini yaitu:

1. Observasi

Adalah teknik pengumpulan data oleh peneliti dengan melakukan pengamatan langsung objek penelitian. Pengamatan bertujuan untuk menghimpun data yang lansung dikumpulkan sendiri peneliti untuk melengkapi data yang sudah ada.

2. Wawancara

Wawancara digunakan untuk memperoleh data tentang variabel - variabel yang diteliti (pengembangan karir, iklim organisasi dan kepuasan kerja). Hasil wawancara tidak dianalisis secara statistik melainkan sebagai bahan informasi bagi penyusunan angket penelitian. Sedangkan alat yang digunakan adalah daftar pertanyaan yang akan digunakan sebagai pedoman wawancara.

3. Quesioner (angket)

Kuesioner merupakan teknik pengumpulan data yang dilakukan dengan cara memberikan seperangkat pertanyaan atau pernyataan tertulis kepada respoden untuk dijawabnya 2013:142).

\section{F. TEKNIK ANALISIS DATA}

Teknik analisis data yang digunakan dalam penelitian ini adalah analisis kuantitatif, yaitu suatu metode analisis yang menggunakan perhitungan angka- angka untuk mengambil keputusan. Kemudian diolah menggunakan SPSS versi 22.0 for windows. 


\section{1) Analisis Regresi Berganda}

Untuk mengetahui pengaruh pengembangan karir (X1), dan iklim organisasi (X2), terhadap kepuasan kerja (Y) digunakan Analisis Regresi berganda dengan persamaan:

$Y=a+b_{1} X_{1}+b_{2} X_{2}+e$

Dimana :

$$
\begin{array}{ll}
\mathrm{Y} & =\text { kepuasan kerja } \\
\mathrm{a} & =\text { konstanta } \\
\mathrm{X} 1 & =\text { pengembangan karir } \\
\mathrm{X} 2 & =\text { iklim organisasi } \\
\mathrm{b} \mathrm{b} \mathrm{b}_{2} & =\text { koefisien regresi } \\
\mathrm{e} & =\text { errors term (kesalahan) }
\end{array}
$$

\section{2) Koefisen korelasi dan koefisen Determinasi}

Untuk mengetahui seberapa kuat hubungan antara variabel bebas dengan variabel terikat dapat diketahui dengan melihat besarnya koefisien korelasi. Pengujian uji $t$ dilakukan dengan bantuan program SPSS versi 22.0 for Window

Nilai koefisien berkisar antara -1 sampai 1. Menurut Sugiyono (2013:250) ukuran korelasi (r) antara variabel yang kuat dan tinggi sebagai berikut:

Tabel 1 Penafsiran Koefisien Korelasi

\begin{tabular}{|c|c|c|}
\hline No & Nilai Korelasi & Penafsiran hubungan \\
\hline 1 & $0,000-0,190$ & Sangat rendah \\
\hline 2 & $0,200-0,390$ & Rendah \\
\hline 3 & $0,400-0,690$ & Cukup kuat \\
\hline 4 & $0,700-0,890$ & Kuat \\
\hline 5 & $0,900-1,000$ & Sangat kuat \\
\hline \multicolumn{3}{|c}{ Sumber: Sugiyono, 2013}
\end{tabular}

Untuk mengetahui keeratan hubungan antara variabel bebas pengembangan karir (X1), dan iklim organisasi (X2), secara bersamasama atau simultan terahadap variabel terikat kepuasan kerja (Y), maka nilai koefisien ganda digunakan formula berikut:

$$
\mathrm{R}_{\mathrm{r}} \mathrm{X1}, \mathrm{X} 2=\sqrt{\frac{r^{2} y x 1+r^{2} y x 2-2 r y x 1 . y x 2}{1-r^{2} \times 1 \times 2}}
$$

Dimana:

$R_{\mathrm{y}} \cdot \mathrm{x} 1, \mathrm{x} 2=$ koefisien korelasi

Selanjutnya untuk menyatakan besar kecilnya sumbangan variabel $X$ terhadap variabel $Y$ dapat ditentukan dengan rumus sebagai berikut :

$R^{2}=r^{2} \times 100 \%$

Dimana:

$\mathrm{R}^{2}=$ nilai koefisien determinasi

$r=$ nilai koefisien korelasi

\section{3) Uji Parsial ( $t$ )}

Uji t digunakan untuk mengetahui pengaruh masing-masing variabel bebas (independen) teerhadap variabel terikat (dependen secara parsial. Pengambilan keputusan berdasarkan perbandingan nilai $t$ hitung dan nilai kritis sesuai dengan tingkat signifikan yang digunakan yaitu 0.05 . pengambilan keputusan didasarkan nilai probalitas yang didapat dari hasil pengolahan data melalui program SPSS versi 22.0 for window.

\section{G. HASIL PENELITIAN}

1) Analisis Regresi berganda

Untuk mengetahui pengaruh pengembangan karir (X1), iklim organisasi (X2),terhadap kepuasan kerja (Y) digunakan Analisis Regresi berganda dengan persamaan: $Y=a+b_{1} X_{1}+b_{2} X_{2}+e$

Hasil analisis regresi berganda terlihat pada tabel berikut: 


\section{Tabel 2 Hasil Coefficient Regresi Coefficients $^{a}$}

\begin{tabular}{|c|c|c|c|c|c|}
\hline \multirow[b]{2}{*}{ Model } & \multicolumn{2}{|c|}{$\begin{array}{c}\text { Unstandardized } \\
\text { Coefficients }\end{array}$} & \multirow{2}{*}{\begin{tabular}{|c}
$\begin{array}{c}\text { Standardized } \\
\text { Coefficients }\end{array}$ \\
Beta
\end{tabular}} & \multirow[b]{2}{*}{$t$} & \multirow[b]{2}{*}{ Sig. } \\
\hline & B & Std. Error & & & \\
\hline 1 (Constant) & 8.602 & 2.916 & & 2.950 & .005 \\
\hline Pengembangan Karir & .254 & .068 & .470 & 3.762 & .001 \\
\hline Iklim Organisasi & .239 & .075 & .400 & 3.203 & .003 \\
\hline
\end{tabular}

a. Dependent Variable: KepuasanKerja

Sumber : Hasil Pengolahan data

Berdasarkan hasil pengujian menggunakan Software SPSS Versi 22.0 for windows yang telah disajikan pada tabel diatas, menunjukan bahwa koefisien regresi untuk variabel pengembangan karir $\left(X_{1}\right) 0,254$, iklim organisasi $\left(X_{2}\right) \quad 0.239$, dan nilai konstanta sebesar 8.602 sehingga persamaan regresi penelitian ini adalah:

$$
Y=8.602+0,254 X_{1}+0,239 X_{2}
$$

Dengan diperoleh persamaan regresi diatas, maka dapat dibaca besarnya pengaruh masing - masing variabel bebas serta hubungamya terhadap variabel dependen sebagai berikut:

a. Koefisien konstanta $\mathrm{a}=8.602$ dimana nilai koefisien pengembangan karir $\left(\mathrm{X}_{1}\right)$ dan iklim organisasi $\left(\mathrm{X}_{2}\right)$ bernilai konstan, maka nilai kepuasan kerja karyawan sebesat 8.602

b. Jika variabel pengembangan karir (X1) dinaikan sebesar satu satuan maka akan meningkatkan variabel produktivitas kerja sebesar $25.4 \%$.

c. Jika variabel iklim organisasi (X2) dinaikan sebesar satu satuan maka akan meningkatkan variabel produktivitas kerja sebesar $23,9 \%$.

\section{2) Koefisien Korelasi}

Untuk mengetahui seberapa kuat hubungan antara variabel bebas terhadap variabel terikat dapat dilihat pada tabel berikut:

Tabel 3

Koefisen Korelasi

\begin{tabular}{|l|l|r|r|r|}
\hline Model & R & R Square & Adjusted R Square & Std. Error of the Estimate \\
\hline 1 & $.658^{\mathrm{a}}$ & .433 & .402 & 4.44146 \\
\hline
\end{tabular}

Sumber: Hasil Pengolahan Data 
Tampilan output SPSS hubungan yang kuat terhadap menunjukan bahwa nilai koefisien kepuasan kerja karyawan pada PT. ganda ( $r$ ) sebesar 0,658, maka dapat PLN (PERSERO) UIW, S2JB UP 3 disimpulkan bahwa pengembangan karir dan iklim organisasi memiliki Lahat.

\section{3) Koefisien Determinasi $\left(\mathbf{R}^{2}\right)$}

Tabel 4

Model Summary

Hasil Koefisien Determinasi

\begin{tabular}{|l|r|r|r|r|}
\hline Model & $\mathrm{R}$ & $\mathrm{R}$ Square & Adjusted R Square & Std. Error of the Estimate \\
\hline 1 & $.658^{\mathrm{a}}$ & .433 & .402 & 4.44146 \\
\hline
\end{tabular}

Sumber : Hasil Pengolahan data

Tampilan output SPSS menunjukan bahwa nilai $R^{2} \quad 0,433$ artinya perubahan variasi kepuasan kerja dapat dijelaskan oleh variabel pengembangan karir dan iklim organisasi dengan kontribusi 43,3\% sedangkan sisanya sebesar $56,7 \%$ dapat dijelaskan oleh variabel lain yang tidak dimasukan kedalam model.

\section{4) Uji Parsial (Uji t)}

Uji t digunakan untuk menguji secara parsial masing- masing variabel. Hasil uji t dilihat pada tabel coeficient pada kolom sig (significance). Jika probabilitas nilai $\mathrm{t}$ atau signifikan $<0.05$, maka dapat dikatakan bahwa terdapat pengaruh antara variabel bebas terhadap variabel terikat. Namun, jika probabilitas nilai $\mathrm{t}$ atau signifikansi > 0,05, maka dapat dikatakan bahwa tidak terdapat pengaruh yang signifikan antara masing-masing variabel bebas terhadap variabel terikat (Sugiyono,2015).

Tabel 5

Hasil Uji Parsial (Uji t)

Coefficients $^{a}$

\begin{tabular}{|c|c|c|c|c|c|}
\hline \multirow[b]{2}{*}{ Model } & \multicolumn{2}{|c|}{$\begin{array}{l}\text { Unstandardized } \\
\text { Coefficients }\end{array}$} & \multirow{2}{*}{$\begin{array}{c}\text { Standardized } \\
\text { Coefficients }\end{array}$} & \multirow[b]{2}{*}{$\mathrm{T}$} & \multirow[b]{2}{*}{ Sig. } \\
\hline & $\mathrm{B}$ & Std. Error & & & \\
\hline 1 (Constant) & 8.602 & 2.916 & & 2.950 & .005 \\
\hline Pengembangan Karir & .254 & .068 & .470 & 3.762 & .001 \\
\hline Iklim Organisasi & .239 & .075 & .400 & 3.203 & .003 \\
\hline
\end{tabular}

Sumber : Hasil Pengolahan data 


\section{H. PEMBAHASAN}

Berdasarkan hasil pengujian menggunakan Software SPSS Versi 22.0 for windows yang telah disajikan pada tabel 5 diatas, menunjukan bahwa koefisien regresi untuk variabel pengembangan karir $\left(X_{1}\right) 0,254$, iklim organisasi $\left(X_{2}\right) \quad 0.239$, dan nilai konstanta sebesar 8.602 sehingga persamaan regresi penelitian ini adalah:

$$
Y=8.602+0,254 X_{1}+0,239 X_{2}
$$

Dengan diperoleh persamaan regresi diatas, maka dapat dibaca besarnya pengaruh masing - masing variabel bebas serta hubungamya terhadap variabel dependen sebagai berikut:

a. Koefisien konstanta $\mathrm{a}=8.602$ dimana nilai koefisien pengembangan karir $\left(X_{1}\right)$ dan iklim organisasi $\left(X_{2}\right)$ bernilai konstan, maka nilai kepuasan kerja karyawan sebesat 8.602

b. Jika variabel pengembangan karir (X1) dinaikan sebesar satu satuan maka akan meningkatkan variabel prestasi kerja sebesar $25.4 \%$.

c. Jika variabel iklim organisasi (X2) dinaikan sebesar satu satuan maka akan meningkatkan variabel prestasi kerja sebesar $23.9 \%$.

d. Nilai koefisien ganda $(r)$ sebesar 0,658, maka dapat disimpulkan bahwa pengembangan karir dan iklim organisasi memiliki hubungan yang kuat terhadap kepuasan kerja karyawan pada PT. PLN (PERSERO) UIW, S2JB UP 3 Lahat.

e. Nilai $R^{2} \quad 0,433$ artinya perubahan variasi kepuasan kerja dapat dijelaskan oleh variabel pengembangan karir dan iklim organisasi dengan kontribusi 43,3
$\%$ sedangkan sisanya sebesar $56,7 \%$ dapat dijelaskan oleh variabel lain yang tidak dimasukan kedalam model.

f. Nilai t hitung pengembangan karir $\left(X_{1)}\right.$ sebesar 3.762 dengan taraf signifikan 0.01 atau ( $P$-value 0.05), maka $\mathrm{Ho}$ ditolak dan $\mathrm{Ha}$ diterima berarti menunjukan adanya pengaruh yang signifikan antara pengembangan karir $\left(X_{1}\right)$ terhadap kepuasan kerja $(\mathrm{Y})$ dan Nilai t hitung iklim organisasi $\left(\mathrm{X}_{2}\right)$ sebesar $3.203>\mathrm{t}$ tabel dengan taraf signifikan 0.03 atau ( $P$ value $0.04<0.05$ ), maka $\mathrm{Ho}$ ditolak dan $\mathrm{Ha}$ diterima berarti menunjukan adanya pengaruh yang signifikan antara iklim organisasi $\left(X_{1}\right) \quad$ terhadap kepuasan kerja $(\mathrm{Y})$.

\section{H. KESIMPULAN DAN SARAN}

1) Kesimpulan

Kesimpulan dari analisis deskriptif antara lain pengembangan karir dinilai dinilai tepat dalam rangka peningkatan kepuasan kerja karyawan. Untuk itu karyawan perlu diberi kesempatan mengikuti studi lanjut atau mengembangkan karir mereka. Hal ini dilakukan untuk meningkatkan kepuasan kerja karyawan. Selain itu, pimpinan juga harus dapat memperhatikan iklim organisasi khususnya lingkungan kerja yang nyaman. Apabila iklim organisasi baik maka dapat meningkatkan kepuasan kerja karyawan. Penelitian ini memberikan hasil bahwa pengembangan karir dan iklim organisasi berpengaruh positif dan signifikan terhadap kepuasan kerja karyawan pada PT. PLN (PERSERO) UIW, S2JB UP 3 Lahat.

\section{2) Saran \\ a. Untuk meningkatkan meningkatkan kepuasan kerja}


berdasarkan pengembangan karir pada PT.PLN (PERSERO) UIW, S2JB UP 3 Lahat harus lebih memperhatikan dan meningkatkan karir karyawan dengan memberikan pelatihan kepada karyawan, memberikan kesempatan kepada karyawan untuk mengembangkan karir mereka, dan saling memberikan dukungan antar karyawan dalam meningkatkan karir..

b. Untuk meningkatkan kepuasan kerja pimpinan harus menciptakan iklim organisasi yang menyenangkan.

c. Peningkatan kepuasan kerja karyawan dapat dimulai dengan memberikan reward agar karyawan lebih terpacu untuk bersaing secara sehat sehingga dapat mencapai prestasi kerja yang ditargetkan, kondisi kerja yang baik, rekan kerja yang baik serta pemberian penghargaan, menjaga hubungan baik antara rekan kerja serta meningkatkan pengetahuan untuk mendukung pelaksanaan pekerjaan agar lebih baik sehingga target kerja akan tercapai dengan baik.

\section{DAFTAR PUSTAKA}

Aziri.B.2011. Job satisfaction: $A$ Litelature Review. Management Reseach and Practice,3(4)

Fitri Afriani.2016. Pengaruh iklim Organisasi terhadap kepuasan kerja pegawai pada kantor kecamatan kepenuhan ulu.
Kadarisma.M. (2013). Manajemen Pengembangan Sumber Daya Manusia. Jakarta:Rajawali Pers.

Kusuma Halim.2010.Iklim Organisasi dan Kepuasan kerja.

Lila Masna.2011.Indikator-Indikator Iklim Organisasi :Jakartaa

Mondy, Wayne R and Judy.2012. Human Resource Mangement. Edisi 12. England

Sunyoto.D.2012.Manajemen sumber Daya Manusia, Cetakan I.Yogyakarta:CAPS

Sunarso. Ahmad.2010.Teori Kepuasan Kerja: Jakarta

Sugiyono.2013. "Metode Penelitian Kuantitatif, Kualitatif dan $R \& D$ ", Cetakan ke-18, Penerbit: ALFABETA, CV.

Veithzal Rivai,M.B.A. 2013. Manajemen Sumber Daya Manusia untuk Perusahaan. PT. Raja Grafindo Persada.

Warjono, Sentot Imam. 2015. Manajemen Sumber Daya Manusia. Jakarta: Salemba Empat

Widya Parimita.2015. Pengaruh Pengembangan Karir dan Motivasi terhadap Kepuasan Kerja Karyawan PT.POS Indonesia Bekasi 